Robbeets, M. (2016). Insubordination and the establishment of genealogical relationship across Eurasia. In N. Evans, \& H. Watanabe (Eds.), Insubordination (pp. 209-245). Amsterdam; Philadelphia: John Benjamins Publishing Company.

\title{
Insubordination and the Establishment of Genealogical Relationship Across Eurasia
} Martine Robbeets (MPI Jena)

\section{Introduction}

Can our understanding of insubordination be brought to bear beyond purely typological issues in historical linguistics? Can it add, for instance, to the establishment of broader genealogical relationships? In this chapter, I will explore the possibility of employing historical-comparative arguments turning on insubordination in the much debated affiliation question of the Transeurasian languages. The label "Transeurasian" was coined by Johanson \& Robbeets (2010: 1-2) to refer to a large group of geographically adjacent languages, traditionally known as "Altaic", that include up to five different linguistic families: Japonic, Koreanic, Tungusic, Mongolic, and Turkic. The question of whether these families go back to a single common ancestor is one of the most disputed issues in historical comparative linguistics. The controversy is not primarily fueled by a shortage of similarities, but by the parts of language structure to which the similarities belong as well as by the difficulty of accounting for them: first, there is the objection that the languages in question may share lexical items, but that they do not have enough bound morphology in common. Second comes the difficulty of distinguishing between similarities generated by borrowing and those that are true residues of inheritance. In this chapter, I intend to show that the historicalcomparative study of insubordination can contribute to the refutation of both objections.

For this purpose, I will first ascribe the Transeurasian insubordination pattern to a special subtype of "direct insubordination", situating it within other mechanisms for developing finite forms from non-finite forms cross-linguistically. Focussing on two sets of cognate suffixes reflecting proto-Transeurasian (henceforth pTEA) $*_{-} r A$ and $*_{-} x A$ in Sections 2 and 3 , I will document a recurrent tendency in the Transeurasian languages for deverbal noun suffixes to develop, first, to markers of syntactically dependent clauses and then, directly to markers of fully independent sentences. In section 4, I will argue that these changes reflect a grammaticalization process, which also triggers the development of tense distinctions from original aspectual distinctions across the Transeurasian languages. Finally, I will propose a way of distinguishing between the effects of borrowing and inheritance in generating shared insubordination between different languages and suggest a plausible way to account for the instances of shared insubordination across the Transeurasian languages.

\section{Direct insubordination and other mechanisms of "finitization"}

The languages of the world use a variety of mechanisms for bestowing finite function on formerly and formally non-finite suffixes, a process, which can be referred to as "finitization". Finite forms can be defined by their morphological marking: they typically carry the maximum marking for such categories as tense, aspect, modality and agreement permitted in the language. They can also be defined by their syntactic function: they prototypically function as the only predicate of an independent clause (Trask 1993: 103-104, Nedjalkov 1995: 97, Givón 2001: 25-26, Bisang 2001, Malchukov 2006, Nikolaeva 2007: 1- 
7). In contrast, verbal nouns, participles and converbs are non-finite verb forms whose prototypical function is to mark argument, adnominal and adverbial subordination respectively.

There are four major pathways by which markers of dependent clauses can come to mark independent clauses. One common strategy is to reduce the matrix predicate to an affix or a particle on the former dependent verb. In example (1), for instance, the matrix verb bimbata 'it is audible' in Ket is reduced to a present suffix - $b$ Eta $\sim$-bata on verbs expressing sound production, whereas the past verb bil'ata 'it was heard' has evolved into the past suffix bileta bil'ata (Malchukov 2013: 196-197).

(1) Reduction of finite verb to affix in Ket

(1a) tam bis' $\varepsilon \eta$ in'y $\varepsilon j$ bi-mbata

PT what sound be.audible-PRS

'a certain sound is audible' (Werner 1997: 170)

(1b) $p$-kutal'ej-beta

1SG.POSS-whistle-PRS

'I whistle' (Werner 1997: 187)

Alternatively, a construction consisting of a nominal predicate plus finite copula can be reanalyzed as a verbal predicate, whereby the copula may be subsequently lost. A classic example is given in $(2 \mathrm{a} / \mathrm{b})$, where in Old Russian a nominal construction plus copula 'the land is the one that came about' is reanalyzed as a verbal predicate 'the land came about' and then, later in Russian, the copula is dropped. The loss of the copula may pass through an intermediate stage in which the former copula grammaticalizes to a sentence-final particle, as is often seen in the Tibeto-Burman languages (DeLancey 2011). The Sizang (Northern Chin) finite clause in (3b), for instance, can be derived from a nominalized construction because the clitic used for verb agreement is a possessive proclitic, also used with nouns as in example (3a). The equational copula $h i$ of the original construction has left a trace in the homophonous final particle.

(2) verbalization of nominal predicates plus finite copula in Russian
(2a) OR
rusk-aja
zemlja sta-l-a
$e s-t \breve{\imath}$

Russian-F.SG land come.about-PERF.PCP-F.SG

be-3SG

'The Russian land has come to exist'

(2b) Rus.

(Tale of bygone years, The Laurentian codex, 1377)

ty spa-l-a

you sleep-PST-F.SG

'You slept'

(3) verbalization of nominal predicates plus finite copula in Sizang

(3a) kâ mei

1POSS tail

'my tail' (DeLancey 2011: 350)

(3b) ká pài: hî:

1POSS go PT

'I go / went' (DeLancey 2011: 350) 
A third strategy involves the entire omission of the matrix predicate and the maintenance of the complement, which then takes on the function of the missing matrix as in example (4) from Japanese where the dependent conditional clause 'if you gave it a try' takes on the pragmatic meaning of the matrix predicate. This is the type to which Evans (2007: 367) applies the term "insubordination", defining it as "the conventionalized main clause use of what, on prima facie grounds, appear to be formally subordinate clauses".

(4) omission of verbal predicate in Japanese

$\begin{array}{lll}\text { (4a) } \begin{array}{ll}\text { yat-te } \\ \text { do-CONV }\end{array} & \begin{array}{l}\text { mi-tara } \\ \text { see-COND how be=INTER }\end{array} \\ \text { (4b) } \begin{array}{l}\text { yat-te } \\ \text { mi-tara? }\end{array} & \text { do-CONV } & \text { see-COND } \\ & \text { 'Why don't you give it a try?' }\end{array}$

Finally, a non-finite predicate may be directly reanalyzed as a finite one, without the omission of a specific matrix predicate, as in example (5) from Barbareño Chumash (Mithun (forthcoming)). Here, the finitisation of the non-finite form occurs through the reanalysis of the subordinate construction as an independent clause. More examples of such direct reanalysis can be found in Dyirbal, Kayardild (Evans 2007: 408-409, this volume), Navajo and Central Alaskan Yup'ik (Mithun 2008).

(5) direct reanalysis of a non-finite verb form in Barbareño Chumash
$K-e-\check{c} a$ 'min
Pal-asnes-waš
1-NEG-know
NML-do-PST
'I don't know how he did it'
No'no Pal-Pitaxmayšis $\quad h i=h e ?=l=$ maliwana.
very NML-be.wonderful $\mathrm{DEP}=\mathrm{PROX}=\mathrm{ART}=$ marijuana
'Marijuana is really wonderful.' (Mithun (forthcoming))

Evans' (2007: 384) requirement that "the resultant construction draws its material from only the old subordinate clause" explicitly excludes the examples in (1), (2) and (3) as instances of "insubordination" because predicate material from the independent clause is retained here. In (1b) the original Ket matrix verb 'be audible' is preserved as a present marker in a reduced form. Evans (2007: 385) explicitly excludes all cases where former main verbs are reduced to suffixes to an erstwhile subordinate verb, which has become the new verb. In (3b) the original copula is preserved as a final particle in Sizang. Although the copula is entirely lost in the contemporary Russian example in $(2 b)$ the ending $-l-a$ reflects predicate material from the independent clause because the former nominal predicate was reanalyzed as a periphrastic perfect verbal predicate before the copula was dropped.

Examples like (5) however, are not excluded by Evan's requirement and they can therefore be regarded as instances of "insubordination", even if they do not involve the ellipsis of a matrix verb. Evans (2007: 409) motivates this by arguing that the lack of a copula in previous language stages meant that participles and nominalizations could serve directly as a finite predicate, without needing an auxiliary verb. Mithun (2008, forthcoming) accounts for this process by the extension of markers of dependency from the level of syntax to the level of discourse. The nominalization begins as a lexical process, deriving nouns from verbs (e.g. 'to do' -> 'deed'). They are then extended to mark whole clauses as syntactically 
dependent, constituents of larger complex sentences, such as 'how he did it' in (5a). Finally, the nominalization extends one step further to mark syntactically independent sentences, which add supplementary information such as the exclamation in (5b).

The process described by Mithun is one of the driving forces of morphosyntactic change in the Transeurasian languages. In the Sections 3 and 4, I will advance empirical data in order to document the recurrent process of insubordination in these languages. These data lead to reconstructed forms in the Japonic, Koreanic, Tungusic, Mongolic and Turkic languages, which will in turn be compared and used to reconstruct Transeurasian proto-forms in Section 6.

\section{3. pTEA *-rA: from aspectually neutral deverbal noun suffix to finite non-past}

\section{1. pJ *-(wo-)ra}

The deverbal noun suffix $\mathrm{pJ} *_{-} r a$ can be reconstructed as a suffix that derived nominal and adnominal forms from verbal adjectives such as in OJ aka- 'to be red' -> akara 'red', usu- 'to be fine' -> usura 'fine', uma- 'to be tasty' -> umara 'tasty', yo $2_{-}^{-}$'to be good' $\rightarrow y_{2} \mathrm{ra}$ ' good', sakasi- 'to be wise' -> sakasira 'wisdom', kanasi- 'to be sad' $\rightarrow$ kanasira 'sadness', EMJ benecessitive -> bera nar- necessitive etc. (Antonov 2007: 102, 111, 128-132, 153, 160, 196, Vovin 2009: 436-440). ${ }^{1}$ Unless OJ tatara 'foot-bellows' can be derived from OJ tat- 'stand' $(<*$ tata- $)$ and this suffix, there are no indications of deverbal derivation.

Clausal (ad)nominalization makes use of a suffix $\mathrm{pJ} *$-oro reflected as $-u r u /-r u /-u$ in Old Japanese and as *-uru / -ru in the Ryukyuan languages, which may go back to a complex form $\mathrm{pJ} * w o-r a$ consisting of a copula $* w o$ - and the deverbal noun suffix *-ra (Robbeets forthcoming: Section 6.3.1.). This is illustrated by the Old Japanese complement clause in (6a) and the relative clause in (6b).

Although the standard use of this suffix is adnominal, it can be used as a finite form marking independent sentences in both Old Japanese (see (6c)) and the Ryukyuan languages. In such cases, the insubordinated form signals the evaluative nature of the proposition and it may be accompanied by focus particles specifying the exact nature of the speakers reaction such as question, exclamation, confirmation, explanation etc., a phenomenon known as kakari-musubi in Japanese.

(6) Developments of the deverbal noun suffix pJ *-ra in Western Old Japanese

(6a) Clausal nominalization

$$
\text { punapi }_{1} \mathrm{to}_{2} \text {-wo } \quad \mathrm{mi}_{1}-\mathrm{ru} \text {-ga } \mathrm{to}_{2} \mathrm{mo}_{2} \mathrm{Si}-\mathrm{sa}
$$

boat.people-ACC see-NML-GEN enviable-NML

'it is enviable to see the boat-people' (MYS 15: 3658; Wrona 2008: 206)

(6b) Clausal adnominalization

op- $i_{1}-k-$ uru $\quad \mathrm{mo}_{2} \mathrm{no}_{2}$

pursue-CONV-come-ADN thing

'the things that pursue [us]' (MYS 5: 804; Vovin 2009: 613)

(6c) Finite

ide ika-ni kokodaku ko ${ }_{1}$ p-uru

Oh why-DAT so.much love-FIN

\footnotetext{
${ }^{1}$ Note that Old Japanese distinguished between two values for later $e, i, o$ in certain syllables, which are indexed with subscripts $i_{1}$ versus $i_{2}, e_{1}$ versus $e_{2}$ and $o_{1}$ versus $o_{2}$.
} 
The examples in (6) suggest that $\mathrm{pJ} *_{-} \mathrm{ra}$ began as an aspectually neutral deverbal noun suffix applied to adjective stems to create noun stems: 'be sad' -> 'sadness'. In Old Japanese - as in most Transeurasian languages - noun stems could be juxtaposed to other nominal to add supplementary information, thus functioning as property nouns, i.e. nominally encoded adjectives: 'be red' -> 'red (oranges)'. While lexical nouns were derived by adding the suffix *-ra directly to verbal stems, clausal nominalizations incorporated the copula *wo- 'to be'. The nominalized auxiliary *wo-ra fused into a suffix and became the imperfective (ad)nominalizer OJ -uru, which marked complement clauses and relative clauses in Old Japanese. The relative clauses with -uru developed one step further to mark present tense in syntactically independent sentences, which added supplementary information in discourse, such as question, exclamation, confirmation or explanation.

\section{2. pK *-(wo-)l}

The clausal (ad)nominalizer $\mathrm{pK} *-l$ can be reconstructed on the basis of $\mathrm{K}-(u) l$, MK $-(\cdot u / o) l .^{2}$ While it may be used for complementation, preceding case suffixes, such as the Middle Korean genitive marker $s$ in (7a), the standard function of MK $-(\cdot u / o) l$ is nominal modification as in (7b). ${ }^{3}$ The contemporary Korean adnominalizer $\mathrm{K}-(u) l$ is usually called "prospective" because reference to the future is the most common meaning today. In Middle Korean, however, MK $-(\cdot u / o) l$ is the default imperfective adnominalizer, in essence time neutral (Martin 2002: 376.) It can be noted, however, that the adnominalizer is reflected in some time expressions like $\mathrm{K}$ onul, $\mathrm{MK}$ wo nol 'today' and $\mathrm{K}$ wolhay, MK wol hoy 'this year', which contain an adnominal form of the verb K $o_{-}^{-}, \mathrm{MK}$ wo- 'to come', deriving from ${ }^{*}$ wo- $[l] \cdot$ nal (come-ADN day) and *wo-l $\cdot$ hoy (come-ADN year), respectively. ${ }^{4}$ Since 'today' and 'this year' are not equivalent to 'the coming day' and 'the coming year', but rather should be interpreted as 'the day that has (just) come' and 'the year that has (just) come', these lexicalized expressions suggest a (recent) perfective interpretation following telic verbs. Compare the use of MK 'wo-no- $n \cdot$ hoy (come-PROC-ADN year) for 'next year', i.e. 'the year that is coming' and MK $\cdot n i-\cdot k e-n \cdot h o y$ (depart-PFV-ADN year) for 'last year', i.e. 'the year that has departed'.

The so-called "modulator" $\mathrm{MK}-\cdot w^{u} / o-$, which has been derived from an original copula $\mathrm{pK}$ *wo- 'to be' by Martin (1996: 13, 83; 2006: 222) sometimes appears before MK $-(\cdot u / o) l$. In case the modified noun is semantically the object of the adnominalized verb, as in example (7b), the modulator is always added; otherwise, the modulator is not obligatory. There are few examples left of lexical nominalization reflecting $\mathrm{pK} *-l$ such as MK $k u c h$ - 'to stop' -> $k u \cdot c h u l$ 'cessation', but it is not unlikely that originally, lexical nouns were derived with $\mathrm{pK}$ $*_{-} l$, while clausal nominalization needed the incorporation of the copula $\mathrm{pK} * w o^{-}$, which would be in line with the behavior of the nominalizer $\mathrm{pK} *_{-} m$ (Robbeets forthcoming: Section 6.4.2).

As a finite marker the suffix $\mathrm{pK} *-l$ precedes the interrogative marker $\mathrm{MK} \cdot k w o$ expressing rhetorical, exclamatory or quoted questions (Martin 1992: 667) and it is

\footnotetext{
2 After a consonant-final stem an epenthetic vowel is inserted. The choice of the Middle Korean allomorphs $-\cdot u l$ or - $\circ$ ol is determined by vowel harmony with the vowel of the preceding syllable.

${ }^{3}$ The dots in the Middle Korean words represent the distinctive pitch of the following syllable: one dot for high, two dots for rising, and unmarked syllables are treated as low.

${ }^{4} \mathrm{MK} / \mathrm{l} /$ drops before $/ \mathrm{n} /$ and the other apicals $/ \mathrm{s} /, / \mathrm{c} /$ and $/ \mathrm{t} /$.
} 
incorporated in the ending of explicit statement $\mathrm{K}-u l i, \mathrm{MK}-(\cdot u / o) \cdot l i$ (Martin 1992: 856-857) and in the subjunctive attentive ending $\mathrm{K}-(u) l a$, MK - $(\cdot u / o) \cdot l a$ (Martin 1992: 851, 2002: 378$379)$, as illustrated in (7c). Whereas the subjunctive attentive is morphologically segmentable into the imperfective adnominalizer and the vocative particle $a$, which usually follows nouns (e.g. K palk-un tal-a (shine-ADN moon-VOC) 'Oh shining moon!'), the explicit ending derives from the adnominalizer and a bound noun MK $i$ 'fact (that); that (which)'.

(7) Development of the deverbal noun suffix $\mathrm{pK} *_{-} l$ in Middle Korean

(7a) Clausal nominalization

$\begin{array}{lllll}\text { sse } & \cdot t w o y & t u \cdot l i-l-s & H H W A-P P Y E N G \cdot \cdot u l & n w o-\cdot k h w o \\ \text { three } & \text { measure } & \text { contain-NML-GEN } & \text { vase-ACC } & \text { place-CONV }\end{array}$

'Placing a vase with a capacity of three cupfuls'

(1459 Wel 10: 119 a; Martin 1992: 873)

(7b) Clausal adnominalization

ccywung-soyng-oy nip-wu-l wos

common.people-NOM wear-MOD-ADN clothing

'clothes that the common people wear' (1459 Wel 8: 65; Lee \& Ramsey 2011: 206)

(7c) Finite

$\begin{array}{lll}\cdot Q I L Q-S I M-\cdot u \cdot l w o & k w o y G w o y & h o-\cdot l-a \\ \text { wholehearted-ADV } & \text { silence } & \text { do-FIN-VOC }\end{array}$

'Be utterly quiet!' (1464 Kumkang 12a; Martin 1992: 851)

The examples in (7) suggest that $\mathrm{pK} *-l$ began as an aspectually neutral nominalizer applied to verb stems to create nouns: 'to stop' $->$ 'cessation'. Noun stems expressing properties could be juxtaposed to other nominal to add supplementary information. Whereas lexical nouns were derived by adding the suffix $*-l$ directly to verbal stems, clausal nominalizations incorporated the copula *wo- 'to be'. Following atelic verb stems, the (ad)nominalizer had an imperfective interpretation, while it was originally interpreted as perfective following telic verb stems. The relative clauses marked with $\mathrm{pK} *_{-}(w o)-l$ developed one step further to mark syntactically independent sentences, which added supplementary information in discourse, such as question, exclamation, confirmation and explanation. As such, the deverbal (ad)nominalizer $\mathrm{pK} *-l$ does not only correspond to $\mathrm{pJ} *-r a$ in form and function, but the correlations also involve the incorporation of a cognate copula *wo- 'to be' in clausal (ad)nominalization and the further development to finite use in particular discourse contexts.

\section{3.pTg *-rA}

The deverbal noun suffix pTg *-rA can be reconstructed as a suffix that derived nominal and adnominal forms from verb stems such as Even $d a: l-$ 'to be sweet, pleasant, light' -> dalra 'sweet, tasty', Even eden- 'to be windy, to blow (of wind)' -> edenre 'windy', Even eman'to snow, fall (of snow)' -> emanra 'snow, snow-' and Evenki langa- 'to break a tooth' -> langara 'toothless' (Nedjalkov 1997: 305)..

The suffix is also used for clausal (ad)nominalization, as illustrated by the Manchu complement clause in (8a) and the relative clause in (8b). In the other Tungusic languages more recent deverbal noun suffixes of the shape pTg *-ri: have replaced the old ones on $*_{-} r A$ in complement and relative clauses. The forms reflecting pTg ${ }_{-} r A$ are maintained however in the finite paradigms throughout all Tungusic languages, including the Manchu example in (8c). 
(8) Development of the deverbal noun suffix pTg $*_{-} r A$ in Manchu

(8a) Clausal nominalization

mama-de $\quad \begin{aligned} & \text { ala-ra-de, } \\ & \text { old.woman-DAT tell-NML-DAT }\end{aligned}$ old.woman
'When [he] tells [it] to the old woman, the old woman says: “...".
(Gorelova 2002: 257)

(8b) Clausal adnominalization

bargiyata-ra niyalma

protect-ADN people

'people who protect [him]' (Gorelova 2002: 485)

(8c) Finite

$\begin{array}{llll}\text { si } & \text { nene-me isinji-ci uthai sin-de } & \text { bu-re } \\ \text { you be.first-CONV come-CONV at.once you-DAT } & \text { give-FIN } \\ \text { 'If you come first, I shall give [it] to you straight away' (Gorelova 2002: 256) }\end{array}$

It can be observed that in some Northern Tungusic languages, such as Even and Evenki, the finite temporal interpretation depends on actional semantics of the verb: derived from telic verbs, $-r A$ refers to the recent past, e.g. Even em-re-n (come-FIN-3SG) '(he) has just come', whereas derived from atelic verbs, it refers to the present, e.g. Even hong-ra-n (weep-FIN3SG) 'he weeps'(Malchukov 2000: 443). This suggests that the Proto-Tungusic clausal adnominalizer $\mathrm{pTg} *_{-} r A$ displayed imperfective or perfective interpretation according to the telicity of the verb base and recalls the etymology of Korean 'today' and 'this year' (Section 2.2).

The examples in (8) suggest that pTg *-ra began as an aspectually neutral deverbal noun suffix: 'to snow' -> 'snow', whereby noun stems expressing properties could be juxtaposed to other nominals 'to snow' $->$ 'snow (man)'. The (ad)nominalizers were then extended to the clause level to mark clausal (ad)nominalization with imperfective or perfective interpretation depending on the telicity of the verb base. The relative clauses developed one step further to mark syntactically independent sentences, which may have initially added supplementary information but gradually generalized into the default indicative present ending.

\section{4. pMo *-r}

The deverbal noun suffix pMo $*_{-} r$ can be reconstructed on the basis of the Written Mongolian and Middle Mongolian suffix - $(\ddot{U}) r$, e.g. WMo. belčige- 'to pasture, graze (tr.)' $>$ belčiger 'pasture, grazing grounds, grass on a pasture', WMo. irüge- 'bless, pray (tr. /intr.)' -> irüger 'prayer, blessing', MMo. / WMo. amu- 'to rest, relax (intr.)' -> amur 'peace, rest; easy', WMo. qayi- 'to hew; cut, chop (tr.)' -> qayir 'gravel, coarse sand, pebbles' and WMo. siba- 'to plaster, apply mud (tr. /intr.)' -> sibar 'mud, plaster; covered with mud' (Poppe 1954: 49; Street 1957: 58). ${ }^{5}$ Derivations from transitive verbs may represent either subject nouns (e.g. WMo. irüger 'prayer', sibar 'mud') or object nouns (e.g. WMo. belčiger 'grass on a pasture, qayir 'gravel'), which suggests that the suffix *-r could express either neutral or resultative aspect.

Relics of clausal nominalization are preserved in the final converb in $-r A$, illustrated in (9a), which can be derived from $*_{-} r$ marking a complement clause plus the dative suffix in $*_{-}$

\footnotetext{
5 The epenthetic vowel $-u-/-\ddot{u}$ - is added when the verb stem ends in a consonant.
} 
$A$ as well as in the preparative converb on -run, which is a compound of $*_{-} r$ and the genitive suffix in *-un (Poppe 1954: 59, 98, 180).

Examples of finite use in Mongolic are lacking, but it is remarkable that among the markers of past tense in Khitan, a sister language of Proto-Mongolic, we find the suffix $-r$, which is only preserved in telic expressions, such as 'become', 'become appointed', 'become awarded', 'compose an edict', 'write this text' (Kane 2009: 145-146); see example (9b).

(9) Development of the deverbal noun suffix pMo $*_{-} r$ in Written Mongolian and Khitan

(9a) Clausal nominalization in Written Mongolian

eke-yügen eri-re od-bai

mother-ACC search-CONV go-PST.FIN

'He went to find her mother' (Sárközi 2004: 47)

(9b) Independent sentence in Khitan

рии giuи shï po-or

fu gong shi become-PST.FIN

'He was appointed a fu gong shi' (Kane 2009: 146)

The examples in (9) suggest that pMo *-r began as a deverbal noun suffix: 'to pray' -> 'prayer', whereby noun stems expressing properties could be juxtaposed to other nominals: 'to relax' -> 'easy (work)'. The (ad)nominalizers were then extended to the clause level to mark clausal (ad)nominalization. There is no evidence that these dependent clauses developed one step further to mark syntactically independent sentences in Mongolic proper, but they probably did in the para-Mongolic language of the Khitan, which suggests a correlation between the telicity of the verb base and the past tense use of the suffix.

\section{5.pTk*-rV}

The deverbal noun suffix pTk $*_{-} r V$ is reflected in Old Turkic as $-A r$ after most simple consonant stems, $-U r$ or $-I r$ after derived consonants stems and $-y U r$ or $-r$ after vowel stems. ${ }^{6}$ It is present in a number of derivational pairs, such as OTk teg- 'to reach, be worth (intr.)' -> tegir 'share, value, price', OTk. tug- 'to be born, to rise (of sun) (intr.)' -> tugar 'sunrise, east', OTk. $\ddot{u} \eta$ - 'to dig a hole in, to hollow out (tr.)' -> ü̈ür 'cave, cavity, something hollowed out' and OTk. yat- 'to lie down (intr.)' -> yatar / yatur '(something) lying down, invalid'. Derivations from transitive verbs may represent either subject nouns (e.g. Tk. keser 'adze') or object nouns (e.g. OTk. üyür 'cave, cavity'), which suggests that the suffix pTk *$r V$ could express neutral or resultative aspect.

In Old Turkic, the adnominalizer - $(A) r$, which is known under the label "aorist", is still productive in relative clauses as in (10a), but it is used more often as a finite predicate as in (10b). Note that the alternative interpretation 'flowing forth' of the construction (flow-CONV come-ADN) in (10a) suggests that the adnominal suffix can have perfective interpretation following telic verbs, 'flowing forth' meaning 'which has come flowing' rather than 'which comes flowing'.

(10) Development of the deverbal noun suffix pTk $*_{-} r V$ in Old Turkic

(10a) Clausal adnominalization in Old Turkic

\footnotetext{
${ }^{6}$ For the assumption that the vowels in OTk - Ar- and - $U r$ - reflect an original copula and for the reconstruction of the stem-final vowel in pTk $*_{-} r V$, I refer to Robbeets (forthcoming: Sections 3.4.1 and 7.3.5.)
} 
ak-ïp kel-ir sogïk suv

flow-CONV come-ADN cold water

'cold water coming up (or flowing forth)' (Erdal 2004: 284-285)

(10b) Independent sentence in Old Turkic

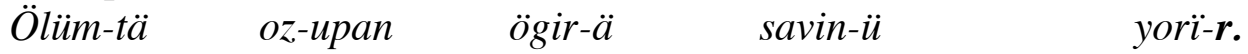

death-ABL escape-CONV rejoice-CONV be.happy-CONV go.on-FIN

'Having been saved from death it happily goes on with its life.' (Erdal 2004: 325)

In Chuvash, the only surviving representative of the Western Turkic branch, the suffix occurs

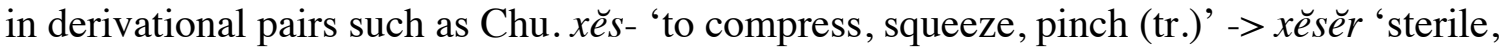
barren'. As illustrated in (11a), Chu. $-r$ further marks perfective relative clauses. In finite position, there are two different reflexes: one is the adnominalizer and finite non-past $-\breve{A}$ in (11a) (Johanson 1975) and the other is the past marker $-(A) r$ in (11b) (Krüger 1961: 143). The development of $-\breve{A}$ and $-(A) r$ as allophonic variants of pTk $*_{-} r V$ can be explained on the basis of phonological conditioning (Robbeets forthcoming: Section 6.3.5.2). It is not unlikely that the allomorph on $-\breve{A}$ spread over the entire verb system, specializing for imperfective and non-past use, while the allomorph - $(A) r$ likewise generalized, specializing for perfective and past use. Thus, in Proto-West Old Turkic, the ancestor of Chuvash, the finite temporal interpretation of the adnominalizer may have depended on the actional semantics of the verb base, as it did in other Transeurasian languages. This functional distinction would originally have been operative on both allomorphs $-\breve{A}$ and $-(A) r$, but gradually $-\breve{A}$ it would have generalized as a marker of present, whereas $-(A) r$ would have come to express the past.

(11) Development of the deverbal noun suffix pTk $*_{-} r V$ in Chuvash

(11a) clausal adnominalization

$\begin{array}{llll}\text { xura vărman } & \text { vitěr } & \text { tux-r-ăm } & \text { čux-ne } \\ \text { black forest } & \text { through } & \text { go.out-PFV.NML-POSS.1SG } & \text { time-DAT }\end{array}$
'When I went out through the black forest'

(11c) non-past

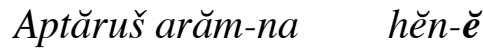

Aptăruš wife-ACC beat-FIN

Aptăruš beats his wife' (Johanson 1975:121)

(11 d) past

văl sirĕ palla-r-ĕ

he you.OBL recognize-PST-3SG

'He recognized you' (Krüger 1961: 146)

The examples in (10) and (11) suggest that pTk *-rA began as a deverbal noun suffix: 'to rise' - $>$ 'sunrise', whereby noun stems expressing properties could be juxtaposed to other nominals: 'to lie down' -> '(thing) lying down'. The (ad)nominalizers were then extended to the clause level to mark clausal (ad)nominalization, having an imperfective or perfective reading depending on the telicity of the verb base. Relative clauses developed one step further to mark syntactically independent sentences with either present continuous or past meaning.

\subsection{The correlations}


The Transeurasian languages preserve evidence supporting the reconstruction of a deverbal noun suffix pTEA *-rA, as illustrated in Table 1 .

Table 1: Transeurasian correlations yielding the reconstruction of pTEA *-rA

\begin{tabular}{|c|c|c|c|c|c|}
\hline pTEA & pJ & pK & pTg & pMo & pTk \\
\hline $\begin{array}{l}\text { *-rA } \\
\text { lexical NML }\end{array}$ & $\begin{array}{l}\text { *-ra } \\
\text { lexical NML } \\
\text { *-wo-ra } \\
\text { clausal NML } \\
\text { clausal ADN } \\
\text { FIN }\end{array}$ & $\begin{array}{l}* \text {-I } \\
\text { lexical NML } \\
\text { *-wo-I } \\
\text { clausal NML } \\
\text { clausal ADN } \\
\text { FIN }\end{array}$ & $\begin{array}{l}\text { *-rA } \\
\text { lexical NML } \\
\text { clausal NML } \\
\text { clausal ADN } \\
\text { FIN }\end{array}$ & $\begin{array}{l}*_{-r} \\
\text { lexical NML } \\
\text { clausal NML } \\
- \\
\text { FIN }\end{array}$ & $\begin{array}{l}\text { *-rV } \\
\text { lexical NML } \\
- \\
\text { clausal ADN } \\
\text { FIN }\end{array}$ \\
\hline
\end{tabular}

The formal correspondences for the vowels $*_{-} a$ - and $*_{-}-2$ - and for the liquid $*_{-} r$ - are regular according to the correspondences established in Robbeets (2005). The vowel harmony archphonemes pTEA *-A- and pTg*-A-represent a retracted tongue root distinction between $*_{-} a$ - and $*_{-}-{ }_{-}$. pTEA $*_{-} a$ - and $*_{-}-$- regularly merges into $\mathrm{pJ} *_{-} a-$. The final vowel in the Korean and Mongolic reflexes of pTEA * $*_{-} A$ has probably been dropped in the course of their individual histories. Vowel erosion in word-final suffixes is to be expected in a process of grammaticalization, especially following sonorants such as $/ \mathrm{m} /$ and $/ \mathrm{r} /$, because their high sonority makes the articulation possible without final vowel.

The functional correspondences lead to the reconstruction of at least the common function of deverbal noun suffix in Proto-Transeurasian. The comparative evidence indicates that pTEA *-rA originated as a deverbal noun suffix, marking a derivational process at the lexical level, was then extended to function as an (ad)nominalizer in dependent clauses at the syntactic level, and was eventually - through its pragmatic role in discourse - extended still further to mark finite forms in independent clauses. There is evidence that some of these developments took place on cognate reflexes of $*_{-} r A$ independently and at different times after separation from Proto-Transeurasian: First, pTEA *-rA underwent an innovation in the Proto-Japanese-Korean branch in the sense that clausal nominalization required a copula construction involving $\mathrm{pJK} *^{*} w o$ - 'to be' plus the deverbal noun suffix. Finite meanining was subsequently developed on the basis of these secondary copula constructions. Second, finite use seems to have still been in development in some historically attested stages, for instance, MK $-(\cdot u / o) l$ still required the addition of a vocative particle or a clitic noun in finite position. These observations suggest that in this case at least finite use has developed independently on cognate nominalizers in the Altaic and Koreo-Japonic branches.

As will be explained in Section 5.2, the aspectually unmarked reflexes of pTEA *-rA developed imperfective adnominal and finite non-past use, whereas the resultative alternants developed perfective adnominal and (perfective) past use. For pTEA $*_{-} r A$, there are derivations of (resultative) object nouns from transitive verbs in Northern Tungusic, Mongolic, Old Turkic and Chuvash. Korean, Northern Tungusic and Chuvash display perfective adnominal use following telic verbs. Indications of finite past use are found in Khitan and Chuvash.

\section{4. pTEA *-xA: from resultative deverbal noun suffix to finite past}

4.1. pJ *-ka

Old Japanese preserves evidence for the reconstruction of a resultative adnominalizer $\mathrm{pJ} *_{-} k a$, 
which derives stative, adnominal forms from original verbal adjectives and change of state verbs such as pJ *koma- 'to be small, fine' in Shuri guma- 'small', Yo. kuma- B 'fine', OJ $k_{1}$ mayaka 'densely (growing)' -> MJ komaka 'fine, small, detailed'; $\mathrm{pJ}$ *nipa- 'to appear suddenly' in OJ nipasi- 'sudden', OJ nipi ' 'new' (OJ - $i$ NML) -> OJ nipaka 'sudden'; pJ *paru- 'to clear, remove (tr.)' in OJ par- B 'to open ground, clear land (cultivation)', OJ paruk- 'to clear up, open up, get bright' -> OJ paruka 'far, distant, remote'; $\mathrm{pJ}$ *saya- 'to become clear, pure' in OJ saye- 'to get clear, bright; get cold', OJ sayame $2^{-}$'to clean, purify (tr.)' -> OJ sayaka 'clear, bright'; OJ tura- A 'to be tough' -> OJ me $e_{2}$ duraka 'strange, rare, precious', etc. The suffix $\mathrm{pJ}{ }^{*}-k a$ is also reflected in the Southern Ryukyuan Miyako dialects. In the Northern Ryukyuan Shodon dialect, it is found as the adnominalizer Sd. -kha, for instance in Qaháá-kha mun (red-ADN thing) 'a red thing'?

Since the suffix is lexicalized in only a few adjectival nouns and thus no longer productive in Old Japanese, there is no evidence left of its original syntactic behavior. Nevertheless, the etymological analysis of $\mathrm{OJ} \mathrm{me}_{2}$ duraka 'strange, rare, precious' in (12a) suggests, that the adnominal verb forms originally could take arguments such as OJ $m e_{2}$ 'eye' in the dative, much like a relative clause. Finite forms ending in $-k a$ such as $y o-k a$ 'it is good', $n a-k a$ 'it is not' are found in parts of Kyushu (Martin 1987: 803); see (12b). Finite use is also found for the corresponding Ryukyuan form Sd. -kha, e.g. in Qaháá-kha (red-FIN) 'it is red'.

(12) The development of the resultative deverbal adnominal suffix $\mathrm{pJ} *-k a$ in Old Japanese

(12a) Clausal adnominalization

OJ $\quad$ me $_{2}$ duraka $\mathrm{pi}_{1} \mathrm{to}_{2}$

pre-OJ *me $e_{2}$-n(i) tura-ka $\quad \mathrm{pi}_{1} \mathrm{to}_{2}$

eye-DAT be.tough-ADN person

(12b) Finite

'strange person'

Kyushu dialects $\quad y o-k a$

good-FIN

'It's good; OK.'

\section{2.pTg *-xA: *-kA:}

In Tungusic, the resultative deverbal noun suffix pTg $*_{-} x a: \sim *_{-} k a$ has been preserved in derivational pairs such as Even ewi:- 'to play (game, instrument) (tr.); to enjoy oneself (intr.)' -> ewi:ke: 'game, toy', hi:l- 'to suffer, be needy, agonize (intr.)' -> hi:lka 'suffering, agony, need; miserable, needy', te: $w$ - 'to put (into), insert, fill (tr.)' -> tepke 'cover, bag, container' and Evenki culbin- 'to grow thin' -> culbika 'thin, meagre', upcu- 'to argue, dispute' $\rightarrow$ upcuke 'disputable' and sukca- 'to ruin' -> sukcaka: 'ruin'. The resultative meaning can be reconstructed because the suffix derives object nouns from transitive verbs (e.g. Even tepke 'cover', ewi:ke: 'toy').

The corresponding resultative nominalizer in Manchu is $-h a \sim-h e \sim-h o$, while about 185 verbs take the "irregular" allomorph $-k a \sim-k e \sim-k o$ (Gorelova 2002: 240-41, 255-256). This allomorphy can be traced back to the Proto-Tungusic level: pTg *- $x A$, yielding Ma. $-h A$, was

\footnotetext{
${ }^{7}$ It is commonly suggested that the Shodon ending - $k h a$ is a reduction from the converb - $k u$ and the copula $a$ 'to be' (Martin 1970: 133; Vovin 2009: 460-461), but this derivation has two problems: first, it cannot account for the aspiration in the Shodon suffix and, second, it fails to explain why $-k h a$, in contrast to other contractions of nominalizer and copula, is not followed by inflected forms of the contracted copula.
} 
used following vocalic stems and stems ending in a stop, whereas the allomorph $\mathrm{pTg} *_{-} k A$, yielding Ma. $-k A$, followed verb stems originally ending in continuants such as $*_{-} n$ - and $*_{-} b$ $(<*-\beta-$-?), e.g. Ma. je- 'eat' -> je-ke, whereby Evk. / Even / Neg. jep-, Na.jep-, Ud. jepte-, Orok deptu-, Sibe je-, Ma. je-, Jurchen je-fu 'to eat' reflect a stem-final $b$ in pTg *jeb- 'to eat', which was already lost in Proto-Manchuric.

The use of the Manchu suffix in complement and relative clauses, illustrated in $(13 \mathrm{a} / \mathrm{b})$ indicates that the resultative deverbal noun suffix was extended to the clause level, marking perfective aspect. As illustrated in (13c), the perfective adnominalizer underwent further insubordination, resulting in the finite past use preserved in Manchu as well as in Even finite warning forms and in Nanai and Udehe finite past markers.

(13) Development of the resultative deverbal noun suffix pTg $*_{-} x A$ : in Manchu

(13a) Clausal nominalization

$\begin{array}{llc}\text { muse ere wakšam-be geli } & \text { wa-ha-de } \\ \text { we this frog-ACC also } & \text { kill-NML-DAT } \\ \text { muke iningdari lakcaraku: } & \text { eye-mbi } \\ \text { water every.day uninterruptedly flow-FIN } \\ \text { 'After we kill these frogs water will flow uninterruptedly' } \\ \text { (SK 68; Gorelova 2002: 257-258) }\end{array}$

(13b) Clausal adnominalization

ere abala-me gene-he gucu-sa

this hunt-CONV go-ADN companion-PL

ji-ci ai seme ala-mbi

come-CONV what reason tell-FIN

'What will (our) companions, who have gone hunting, tell (us) when they return?'

(SK 64; Gorelova 2002:257)

(13c) Finite

ahu:n ji-he turgun-de, deo gene-he

elder.brother come-ADN reason-DAT, younger.brother go-FIN

'Since the elder brother came, the younger brother went away' (Gorelova 2002: 488)

Note that the Manchu past form in $-h A$ alternates with a form in $-h A b i$, which is derivable from the perfective adnominalizer Ma. $-h A$ and the predicative copula bi (Gorelova 2002: $123,232,290-91,444,470,533)$. It can be argued that the Manchu alternant in - $h A$ reflects the original construction and that the copula was added later because in the Northern and Southern Tungusic languages the finite past suffix is never accompanied by a copula. This is supported by the observation that there is no alternative past form in $* *-k A b i$, in which the copula would have followed the original allomorph of Ma. - $h A$. Therefore, Ma. - $h A b i$ can be considered as a case of "direct insubordination" with later copula addition.

\section{3. pMo *-xa $\sim *$-kA}

The Mongolic languages preserve evidence for the reconstruction of a resultative deverbal noun suffix pMo ${ }^{*}-x A$, with intervocalic allophone $*_{-} \gamma A$, e.g. in WMo. edï- 'to begin, start, commence (tr.)' -> edïge 'now, at present, contemporary (adj./adv.)', ide- 'to eat, consume

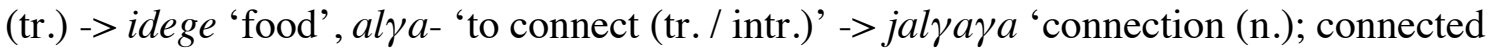
(adj.)' and kebte- 'to lie down, recline (intr.)' -> kebtege 'lying down, horizontal (adj./adv.)'. Since the suffix derives object nouns from transitive verbs (e.g. idege 'food') and stative 
property nouns from change of state verbs (e.g. edüge 'contemporary'), it can be reconstructed as an original resultative marker. There are at least two derivational pairs, i.e. WMo. cubu- 'move one after another in single file; to fall in drops or single grains' -> cubqa 'leaves of a tree' in čubqa julyura- 'leaves are falling of' and WMo. toyuri- 'to go about, circle, surround (tr.) $\rightarrow>$ torurqa 'the encirclement of the tent', which suggests that intervocalic pMo $*_{-} \gamma A$ - lost frication and allophonic voicing following $*_{-} r$ - or $*_{-} b$ (intervocalic [ß]). The devoicing in continuant environment suggests that the original morpheme had a velar fricative onset, i.e. $\mathrm{pMo} *_{-} x A$ and underwent defricativization in certain continuant environments such as following $*_{-} r$ - and $*_{-} \beta$ - (Robbeets forthcoming: Section 6.6.4).

The suffix also appears as a perfective marker in complement or relative clauses, often modifying temporal expressions derived from a noun in the dative case, such as inaqsi(-da) (this side-DAT) 'as long as not', udu'ui(-e) (still.lacking-DAT) or edügüi (still.lacking) 'before, not yet' in (14a). As illustrated in (14b), the suffix has developed finite use with imperfect temporal meaning (Poppe 1954: 94; Weiers 1966: 197; Sárközi 2004: 44; Orlovskaya 1999: 101).

In the para-Mongolic language of the Khitan, the suffix is reflected as - gi before front vowels and $-h u /-h o$ before back vowels and it is used in perfective clausal adnominalization and finite past marking (Kane 2009: 121, 154, 155-156).

(14) Development of the resultative deverbal noun suffix pMo ${ }^{*}-x A$ in Middle Mongolian (14a) clausal (ad)nominalization

\begin{tabular}{|c|c|c|c|c|}
\hline $\begin{array}{l}\text { asa } \\
\text { esides }\end{array}$ & $\begin{array}{l}\text { ber } \\
\text { PT }\end{array}$ & $\begin{array}{l}\text { nasun-dur } \\
\text { long.time-DAT }\end{array}$ & $\begin{array}{l}\text { kürü-ge } \\
\text { reach-NML }\end{array}$ & $\begin{array}{l}\text { edïgüi } \\
\text { still.lacking }\end{array}$ \\
\hline
\end{tabular}

(14b) finite

Sigi Qutuqu ese abu-'a

Sigi Qutuqu NEG take-FIN

'Sigi Qutuqu has not accepted anything' (SH 252; Weiers 1966: 198)

Note that in Middle Mongolian the use of a copula following -'A seems to be rather rare, while its contemporary reflex, the Khalkha continuative - $g . A A$ occurs more frequently with a copula yum. Having made a rough count, Rybatzki (p.c.) finds that in Middle Mongolian, nominalizers indicating finite forms occur more frequently without intervention of a copula than in contemporary Mongolian and therefore assumes that the use of a copula may be a secondary development.

\section{4. pTk *-xA * * $k A$}

The Turkic languages preserve evidence for the reconstruction of a resultative deverbal noun suffix pTk $*_{-} x A$, with intervocalic allophone ${ }^{*}-\gamma A$, e.g. OTk. köli- 'to be shady, shaded; to shade, give shade to (tr./intr.)' -> OTk. kölige 'shadow, deep shade'; OTk. kükre- 'to thunder (intr.)' -> kükrege 'thundering'; OTk. til- 'to cut into strips (tr.)' -> tilge 'strip', OTk kïs- 'to pinch, squeeze, reduce (tr.)' -> kïsga 'short', etc. Since the suffix can derive object nominals from intransitive verbs (e.g. OTk. tilge 'strip') and stative property nouns from change of state verbs (e.g. kïsga 'short'), it can be characterized as a resultative marker. Some derivational pairs, such as OTk. öp- 'to kiss, sip or suck in the air or a liquid' ->öpke 'generated in the lung; lung, anger'; OTk ötür- 'to cause or force to pass through' -> ötürke 
'purgative' and OTk. tar- 'disperse, send away (tr.)' -> tarka 'alone, lonely' suggest that intervocalic pTk *- $\gamma A$ - lost frication and allophonic voicing following $*_{-} r-$ or $^{*}-b-(<* \beta)$. The devoicing in continuant environment suggests that the original morpheme had a velar fricative onset, i.e. pTk $*_{-} x A$ and underwent defricativization in certain continuant environments such as following $*_{-} r$ - and $*_{-} \beta$ - (Johanson 1979, 2012; Robbeets forthcoming: Section 6.6.5).

Although there are no attestations in which the suffix functions as a clausal adnominalizer, it has developed into a marker of finiteness, denoting future meaning such as in example (15) below (Erdal 1991: 382, 2004: 242).

(15) Development of the resultative deverbal noun suffix pTk $*_{-} x A$ in Old Turkic

$\begin{array}{lcr}\check{c} \text { eviš ay- } u \quad \text { ber-ge } & \text { men } \\ \text { method explain-CONV give-FIN } & 1 \mathrm{SG} \\ \text { 'I will explain the method for you' } & (\mathrm{KP} 75,2)\end{array}$

\subsection{The correlations}

The Transeurasian languages preserve evidence supporting the reconstruction of a deverbal noun suffix pTEA $*_{-} x A \sim *_{-} k A$, as illustrated in Table 2 .

Table 2: Transeurasian correlations yielding the reconstruction of pTEA $*_{-} x A \sim *_{-} k A$

\begin{tabular}{|c|c|c|c|c|c|}
\hline pTEA & pJ & pK & pTg & pMo & pTk \\
\hline $\begin{array}{l}* \text {-xA } \sim_{\text {-kA }} \\
\text { lexical RES.NML } \\
\text { clausal PFV.NML } \\
\text { clausal PFV.ADN }\end{array}$ & $\begin{array}{l}\text { *-ka } \\
\text { lexical RES.ADN } \\
- \\
\text { clausal RES.ADN } \\
\text { RES.FIN }\end{array}$ & & $\begin{array}{l}\text { *-xA: } * \text {-kA: } \\
\text { lexical RES.NML } \\
\text { clausal PF.NML } \\
\text { clausal PF.ADN } \\
\text { PST.FIN }\end{array}$ & $\begin{array}{l}*-\mathbf{x A} \sim *-\mathbf{k A} \\
\text { lexical RES.NML } \\
\text { clausal PF.NML } \\
\text { clausal PF.ADN } \\
\text { PST.FIN }\end{array}$ & $\begin{array}{l}*-\mathbf{x A} \sim *-\mathbf{k A} \\
\text { lexical } \\
\text { RES.NML } \\
- \\
- \\
\text { FUT.FIN }\end{array}$ \\
\hline
\end{tabular}

The vowels involved in the comparisons correspond regularly according to the correspondences given in Robbeets (2005). The correspondences of the velar show a particular behavior in such a way that they have lead to the reconstruction of a fricative pTEA * $x$ (see Robbeets 2013b), in addition to the consonant inventory reconstructed in Robbeets (2005: 373). Since the velar involved becomes a voiceless obstruent in a continuant environment, I have suggested that it arose through de-fricativation.

The functional correspondences lead to the reconstruction of at least the common function of lexical/clausal nominalizer and relativizer in Proto-Transeurasian. The comparative evidence indicates that pTEA $*_{-} x A \sim *_{-} k A$ originated as deverbal noun suffix, was then extended to function as an (ad)nominalizer in dependent clauses, and was eventually extended still further to mark finite forms in independent clauses. The Turkic reflex of the perfective (ad)nominalizer pTEA $*_{-} x A$ specializes as a perfective future adnominalizer and further develops future finite meaning, whereas the future connotation is absent from the other Transeurasian languages. This suggests that the development of finiteness took place on cognate reflexes of $*_{-} x A$ independently in Japonic, Mongolo-Tungusic and Turkic.

In contrast to the aspectually neutral deverbal noun suffix pTEA *- $r A$, the reflexes of pTEA $*_{-} x A$ can be characterized as resultative because they derived object nouns from any transitive verb or stative nouns and adjectives from change of state verbs. In the process of insubordination, the suffix developed stative adnominal and non-past meaning when attached to change of state verbs, including verbal adjectives, while it developed perfective adnominal 
and perfective (non-)past meaning following other verbs.

\section{Direct insubordination and the development of tense in the Transeurasian languages 5.1. Direct insubordination as a grammaticalization process}

From classical definitions of grammaticalization such as Kurylowicz (1965: 52): "the increase of the range of a morpheme advancing from a lexical to a grammatical, or from a less grammatical to a more grammatical status" or Heine \& Reh (1984: 15): "an evolution whereby linguistic units lose in semantic complexity, pragmatic significance, syntactic freedom and phonetic substance", it becomes clear that grammaticalization consists in an increase of grammatical status and a loss of semantic content, phonetic substance, categorial properties and syntactic freedom, aspects all of which can be found in direct insubordination.

First, direct insubordination involves an increase of grammatical status. Finite suffixes are typically inflectional: they are fully productive, generally applicable and do not change the word-class of the base. Non-finite suffixes are more towards the derivational end of the morphological scale because they change the word-class of the base. ${ }^{8}$ Suffixes for the derivation of deverbal nouns are relatively derivational because they do not apply productively to all bases, while suffixes for the derivation of participles and converbs are on the interface between derivation and inflection: they are category-changing but also generally applicable and productive. In view of factors such as paradigmatic organization, productivity, syntactic relevance etc., inflectional morphemes reflect a higher grammatical status than derivational morphemes. Therefore, the gradual transition from derivation to inflection reflects an increase of grammatical status, whereby the cline is from deverbal noun affixes over participial affixes to finite affixes.

Second, semantic content is gradually lost as one moves on the insubordination cline. Contrary to finite markers, non-finite suffixes may change the meaning of the base. The Old Turkic deverbal noun tug-ar, for instance, can have various concrete meanings such as 'sunrise' and 'east', but the finite form always means '[she/he/it] rises'.

The clausal adnominal and finite affixes may be phonologically reduced vis-à-vis their deverbal nominal sources; see for instance the assumed contractions in Japanese copula constructions plus $\mathrm{pJ}^{*_{-}} \mathrm{ra}$ or the loss of the final vowel in the development of $\mathrm{pTk} *_{-}(A) r V$.

Fourth, direct insubordination involves loss of categorial properties because it can be viewed as a gradual process of de-nominalization. As Malchukov (2004: 88- 93) explains, the loss of nominal properties is gradual and follows a cline, starting with the loss of case markers, to the loss of possessive marking to the loss of number marking.

Finally, syntactic freedom is lost because the use of the suffixes becomes more and more obligatory in the process of direct insubordination; whereas the use of a deverbal noun is optional in a sentence, the use of finite markers is obligatory.

\subsection{Temporal from aspectual distinctions}

In the etymologies under discussion, the insubordination process is intertwined with yet

\footnotetext{
${ }^{8}$ In the continuum approach the distinction between derivation is conceptualized as opposite poles on a morphological scale (e.g. Bybee 1985, Dressler 1989, Plank 1998). Since non-discrete criteria such as semantic content, semantic relevance to base meaning, semantic transparency, syntactic relevance, paradigmatic organization, morpheme distance from root, etc. help us to distinguish between derivation and inflection, the continuum approach has overwhelming advantages.
} 
another grammaticalization process,i.e. the development of temporal from aspectual distinctions. The grammaticalization from deverbal noun suffix to adnominalizer to finite suffix involves a change in the part-of-speech status from noun to adjective to verb. The nonfinite forms reflecting pTEA *-rA mainly display aspectually unmarked meaning, while the non-finite forms reflecting pTEA $*_{-}-x A$ have resultative meaning. When these forms are verbalized, an actional interpretation is forced on an originally adnominal and therefore more stative form. This leads to the development of tense distinctions from original aspect distinctions, a cross-linguistically well-attested process.

In the majority of cases, the reflexes of the deverbal noun suffix pTEA $*_{-} r A$ are aspectually unmarked and develop to imperfective adnominal to non-past finite. There are some relics however, as in the examples from Korean, Northern Tungusic, Khitan Mongolic and Chuvash, in which pTEA *-rA has developed perfective adnominal and eventually recent past meaning, usually in cases where the base verb had telic semantics. This dependence on the telicity of the base verb can be explained by Bybee's (1985: 147) observation that "Languages do not show one aspect as clearly unmarked and the other marked because for some verbs (in particular, activity verbs and stative verbs), imperfective is the conceptually unmarked member, while for other verbs (in particular, telic or event verbs), perfective is the conceptually unmarked member." Different conceptualizations may even occur on the same base verb. Some verbs can be conceptualized as "atelic" when unaccompanied by an object (e.g. He writes) and telic when an object is present (e.g. He writes a novel). The deverbal noun of the verb 'write' can then be interpreted in both the imperfective sense 'my writing' or in the perfective sense 'my written thing'. When taking up main-clausehood, the nonfinite form may either develop a present interpretation 'I write' or a perfect / past one 'I have written'. This is probably what has lead Chuvash to spread both interpretations on the reflexes of a single original suffix, no longer dependent on the telicity of the base verb. The hypothesized path of diachronic evolution of the resultative deverbal noun suffix pTEA *- $x A$ is from a perfective adnominal into a past finite marker. This is a universal path of evolution, well-attested cross-linguistically (Comrie 1976: 99-101; Bybee 1985: 196; Bybee et al. 1994: 86; Johanson 2000; Malchukov 2000: 447). Note that the development from a resultative into a finite future in Turkic, can also be explained over a perfect with non-past reference, as in German Morgen bin ich schon abgefahren 'I'll already be gone tomorrow'. Comrie (1976: 66) gives examples of this development in ancient Greek and Russian.

\section{Distinguishing borrowing from inheritance in shared insubordination 6.1. Insubordination shared through language contact}

In Robbeets 2015 (submitted), I have argued that the direct insubordination shared across the Transeurasian languages is inherently distinct from the mechanism for developing finiteness in other languages and families in Asia, such as Yukaghir, Sinitic or Tibeto-Burman that develop finiteness from clausal nominalization in construction with a copula. In these languages final particles and focus markers often leave a trace of an eroding copula as in example (3) above.

This does not mean, however, that the frequency and concentration of the process of direct insubordination in the Transeurasian languages by itself should be taken as evidence of common ancestorship. Mithun (2008: 102) finds that processes here referred to as "direct insubordination" are undoubtedly more common crosslinguistically than has hitherto been recognized, partly because traditional studies have focussed on isolated sentences than on longer stretches of discourse. Moreover, direct insubordination seems to be rather common in 
the wider Transeurasian contact zone, appearing among others in Uralic languages, Eskimo and Nivkh. In Nivkh, for instance, the deverbal action noun and infinitive suffix - $d$ ' has developed via participial use into a finite form $-d$ ', as illustrated in example (16), which illustrates both the nonfinite and finite use of the suffix. Since Nivkh has had close contact with Tungusic languages situated to the east such as Olcha, Oroch, Orok, Nanai, Udehe, Negidal and Evenki, it is not unlikely that the development was induced by language-contact. Note that Anderson (2006: 25) finds that "the features of the Siberian linguistic macro-area cluster around those of the Northern Tungusic languages" and refers to the Tungusic languages as "vectors of diffusion".

$\begin{array}{ll}\text { (16) Nivkh } \quad \text { If } \quad \text { hum-d' } & \text { hyjm-d' } \\ \text { he live-NML know-FIN } \\ \text { 'He knows the living one.' } \\ \text { 'He knows (his) life.' (Malchukov 2004: 121; 2013: 200) }\end{array}$

\subsection{Globally shared insubordination as a strong indication of genealogical relatedness}

Even if direct insubordination can diffuse from one language to another as it probably did in the Siberian area, there are indications that the direct insubordination shared across the Transeurasian languages has a genealogical explanation. The main indication is that the process of direct insubordination is shared by formally corresponding suffixes, such as the common forms $*_{-} r A$ and $*_{-} x A$ above. In Robbeets 2013a, I distinguished five different types of shared grammaticalization, i.e. through (i) universal principles, (ii) contact, (iii) contact reinforced by formal coincidence, (iv) inherited polysemy and (v) parallelism in drift and characterized them according to their likelihood of being global (displaying a complete correspondence including form) or selective (involving only a partial correspondence excluding form). ${ }^{9}$ I found that globally shared grammaticalization is highly infrequent in instances of shared grammaticalization that cannot be explained by genealogical factors, such as those induced by universal principles or contact. This led to the assumption that globally shared grammaticalization is a strong indication of genealogical relatedness.

This does not mean, however, that the outcome of a grammaticalization process cannot be globally borrowed. The Yakut suffix -TAx, for instance, functions as a non-finite conditionaltemporal marker (see (17a)) as well as a finite presumptive-assertive suffix (see (17b)). The Sebjan Küöl dialect of Evenki has borrowed this marker, but, as illustrated in (18), restricted to finite use only. This borrowing behavior is different from the shared insubordination in the etymologies under discussion because the non-finite source of grammaticalization is not borrowed.

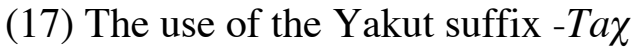
(17a) ol hüöhü-ge
ülele:-te $\chi-\chi e$

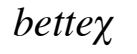
kel-e- $\gamma$ in
that livestock-DAT work-NML-DAT
this.side come-IPF-FIN.2SG
'when working with the cattle you came here' (Pakendorf corpus, p.c.)

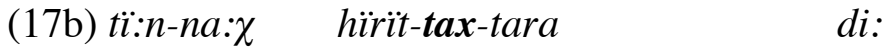

\footnotetext{
9 Inspired by Johanson's code-copying terminology (2002), I will use the term "globally shared grammaticalization" to refer to cases in which the source and the target of a grammaticalization process are shared in addition to form and "selectively shared grammaticalization" to refer to cases of shared grammaticalization without formal correlation.
} 
breath-PROP go-ASS.FIN-POSS.3PL EMPH

'[Keeping cattle for themselves] they stayed alive' (Pakendorf 2009: 91)

(18) The use of the Sebjan Küöl Even suffix -dag-

herile-du a:yyaj-dak-pit di:

stony.mountain-DAT stop.for.the.night-ASS.FIN-POSS.1PL EMPH

'we spent the night on a stony mountain' (Pakendorf 2009: 93)

First let us examine how a borrowing scenario would need to be constructed. The global correspondences of $*_{-r} r$ would need to be explained as follows: first, the recipient language, say Mongolic, borrowed nominalized verbs of the model language, say Turkic. Second, the contact was intensive in such a way that the underlying verb roots were borrowed as well. Third, following a massive borrowing of verb roots, Mongolic speakers saw the relation between the borrowed verb base and the borrowed nominalization and started to apply $*_{-} r A$ productively in their own language. At this stage, Mongolic had globally copied the Turkic suffix, but the borrowing of the outcome of grammatical change was yet to come. Later in the history of Turkic, the nominalizer developed into a marker of finiteness. Fifth, Mongolic speakers, drawing an equivalence between their earlier borrowed nominalizer *-rA and the Turkic adnominalizer, fill the gap by borrowing the finite function. This process would then need to be repeated pairwise four times between Mongolic and Tungusic, Tungusic and Koreanic and so on, until it reaches the Japonic languages. Needless to say; such a complicated borrowing scenario, where one has to invoke chance in case after case, is highly unlikely.

Moreover, in the case of the resultative adnominalizer $*_{-} x A$, we should also explain how the "irregular" allophony with $*_{-} k A$, which was restricted to a limited number of items in a very specific environment following the continuants $* r$ and $* \beta$, was borrowed across Tungusic, Mongolic and Turkic. Note that borrowing tends to reduce allomorphy; in the examples (17) and (18) above for instance, the Yakut suffix in -TAx- has a number of consonantal allomorphs - $t A x-,-l A x$-, $-d A x$ - and $-n A x$ - depending on the preceding stem-final consonant, whereas the allomorphy is reduced to a single variant in Sebjan Küöl Even -dag-.

Additional indications against borrowing are the observation that the globally shared grammaticalization (i) concerns two interrelated pathways, insubordination here being systematically intertwined with the development of tense from aspect; (ii) involves not only a shared source (i.e. deverbal noun suffix) and a shared target (i.e. finite marker), but also intermediate stages of grammaticalization (i.e. clausal (ad)nominalization); (iii) is not restricted to contact zones, being distributed across low contact languages such as Turkic and Japonic or displaying a gap for the Korean reflex of $*-x A^{10}$; (iv) involves the development of a less grammaticalized to a more grammaticalized bound morpheme, the source of insubordination being a "copy-proof" bound morpheme rather than a lexeme; (v) spreads over more than two language families, i.e. Turkic, Mongolic, Tungusic, Koreanic and Japonic and (vi) concerns a specific pathway of grammaticalization which is recurrent in more than one cognate set, insubordination being discussed for two cognate sets $*_{-} r a$ and $*_{-} x A$ here and found to recur in at least five cognate sets in Robbeets (forthcoming: Chapter 7). As a particularly telling instance of globally shared grammaticalization, shared insubordination

10 The absence of a Korean reflex of $*_{-} x A$ raises problems within a borrowing scenario, because direct transfer of the suffix from Tungusic into Japanese is unlikely, given the low contact history between both languages. 
can thus be brought to bear on the establishment of genealogical relationship across the Transeurasian languages.

\subsection{Inherited polysemy or inherited mechanism?}

Globally shared grammaticalization thus points to a common origin of the languages concerned. However, there are two possible ways in which a common linguistic origin may trigger globally shared grammaticalization. The first possibility is that the grammaticalization process was already completed on a specific morpheme in the proto-language, yielding ancestral polysemy. This polysemy was then inherited on the reflexes of this morpheme in the daughter languages. The second scenario, however, is that the grammaticalization process as such was a recurrent mechanism in the proto-language but it had not yet affected the specific morpheme. Due to the disposition of a given language to repeat the 'same' grammaticalization processes over and over again, the grammaticalization took place on the reflexes of the morpheme in the daughter languages, independently and at different times after separation from the proto-language. The latter phenomenon, which is known as "parallel drift" or "Sapirian drift" seems to guide cognate morphemes over family-inherent pathways of grammaticalization (Sapir 1921: 171-172; Meillet 1921: 36-43; Malkiel 1981; Keller 1994; LaPolla 1994; Joseph 2006, 2013; Aikhenvald 2013).

According to Joseph (2012: 163-164) "parallel drift" has a socio-linguistic explanation: "one should entertain the possibility that there was proto-language variation between $\mathrm{X}$ and $\mathrm{X}$ ', where one is the fuller form and the other the apparently "grammaticalized" form, and posit further that each language inherited that variation and that the "grammaticalized" form bubbled up after being sociolinguistically suppressed." Sociolinguistically suppressed in this context seems to refer to the marginal presence of the grammaticalized form in the protolanguage, either because it was used by a small group of speakers only, or because its productivity was restricted to the derivation of a limited set of forms only.

Although I believe that Joseph's account may be part of the explanation of parallel drift, in many cases it may not be necessary to posit submerged variation in the proto-language. The phenomenon may have a more obvious structural explanation. It is based on the expectation that languages try to maintain pre-existing categories in spite of formal renewal. Therefore, newly inserted items will be guided over family-specific pathways of grammaticalization to restore old categories (Heath 1998, Aikenvald 2013). In this way, prior pathways of grammaticalization become decisive in shaping the new ones within a language family.

The comparative evidence summarized in Table 3 suggests that some of the insubordination took place on cognate suffixes independently and at different times after separation from Proto-Transeurasian.

Table 3: Comparison of the development of finiteness on common deverbal noun suffixes in the Transeurasian languages

\begin{tabular}{|l|l|l|l|l|l|}
\hline \multicolumn{1}{|c|}{ pTEA } & \multicolumn{1}{c|}{ pJ } & \multicolumn{1}{c|}{ pK } & \multicolumn{1}{c|}{ pTg } & \multicolumn{1}{c|}{ pMo } & \multicolumn{1}{c|}{ pTk } \\
\hline *-rA & *-ra & *-I & *-rA & *-r & *-rV \\
lexical NML & lexical NML & lexical NML & lexical NML & lexical NML & lexical NML \\
& *-wo-ra & *-wo-I & & & \\
& clausal NML & clausal NML & clausal NML & clausal NML & - \\
& clausal ADN & clausal ADN & clausal ADN & - & clausal ADN \\
& FIN & FIN & FIN & FIN & FIN \\
\hline
\end{tabular}




\begin{tabular}{|l|l|l|l|l|l|}
\hline & & & & \\
\hline *-xA *-kA & *-ka & & *-xA: *-kA: & *-xA *-kA & $*$-xA *-kA \\
lexical & lexical & lexical RES.NML & lexical RES.NML & lexical \\
RES.NML & RES.ADN & & clausal PF.NML & clausal PF.NML & RES.NML \\
clausal & - & clausal PF.ADN & clausal PF.ADN & - \\
$\begin{array}{l}\text { PFV.NML } \\
\text { clausal }\end{array}$ & clausal & PST.FIN & PST.FIN & - \\
PFV.ADN & RES.FDN & & & & FUT.FIN \\
\hline
\end{tabular}

In the deverbal noun suffix pTEA $*_{-} x A \sim *_{-} k a$, the grammaticalization to the clausal(ad)nominalization was already accomplished in Proto-Transeurasian and inherited as polysemy in the daughter languages. However, the development to finite use, took place independently in Japonic, Turkic and in the common ancestor of Tungusic and Mongolic.

The Proto-Transeurasian deverbal noun suffix *-rA with neutral or resultative interpretation depending on the telicity of the base, for instance, may have been accomplished in Proto-Altaic, i.e. the common ancestor of Tungusic, Mongolic and Turkic. However, the Proto-Japanese-Korean branch underwent a common innovation in the sense that it incorporated a common copula *wo- 'to be' for the derivation of clausal (ad)nominalization. The new copula construction developed finite use along the family-inherent pathway of insubordination. These developments are in accordance with the branching of the family, proposed on the basis of shared innovations in lexical comparison (Robbeets 2005), illustrated in figure 1.

Figure 1: The Transeurasian family tree

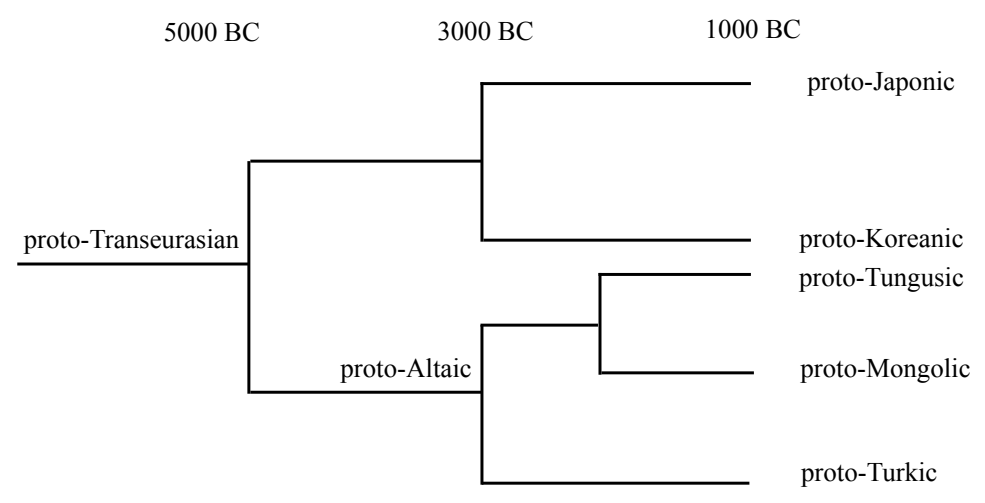

\section{Conclusion}

In this chapter, I have explored the possibility of employing historical-comparative arguments turning on insubordination in solving the longstanding affiliation question of the Transeurasian languages. For this purpose, I have examined the diachronic developments taking place on two sets of deverbal noun suffixes, yielding the reconstruction of pTEA *-rA and pTEA $*_{-} x A$. The comparative evidence, summarized in Table 3 , indicates that these markers originated as deverbal noun suffixes, marking a derivational process at the lexical level, were then extended to function as (ad)nominalizers in dependent clauses at the syntactic level, and were eventually - through a pragmatic role in discourse - extended still further to mark finite forms in independent clauses. This is a development to which Evans' 
(2007: 367) term "insubordination" can be applied because suffixes marking dependent clauses become conventionalized as markers for independent clauses and because the suffix material is drawn from only the former dependent clause. Since the examples given above do not involve the ellipsis of a matrix verb, they can be subsumed under "direct insubordination": the nominalized forms are directly reanalyzed as finite forms rather than being part of an original copula construction which became verbalized and then lost its copula.

I have argued that from a morphological perspective, "direct insubordination" can be regarded as an instance of grammaticalization because the change from non-finite to finite function involves an increase of grammatical status, whereby the morpheme proceeds from the derivational towards the inflectional end of the morphological continuum. Furthermore, in the languages under discussion, insubordination is systematically interrelated with yet another grammaticalization process, i.e. the development of temporal from aspectual distinctions. In the process of insubordination, aspectually unmarked deverbal noun suffixes such as pTEA *-rA tend to develop to imperfective adnominal to non-past finite forms, whereas resultative deverbal noun suffixes such as $*_{-} x A$ tend to develop from perfective adnominal into a past finite marker. There are some indications from Korean, Northern Tungusic, Khitan Mongolic and Chuvash, however, suggesting that aspectually unmarked deverbal noun suffixes may develop perfective adnominal and eventually recent past meaning, especially in cases where the base verb had telic semantics.

It is not really surprising that the Transeurasian languages share direct insubordination as a structural feature, given the fact that the development is not uncommon worldwide and occurs elsewhere in the Siberian area. What is more telling, however, is that the etymologies under discussion reflect globally shared grammaticalization: the source (i.e. deverbal noun suffix), intermediate stages (i.e. clausal (ad)nominalizer) and target (i.e. finite marker) of a grammaticalization process are shared by formally corresponding morphemes. In previous research, I have shown empirically that there are only very few cases cross-linguistically, where globally shared grammaticalization can be explained by non-genealogical factors. Therefore, I have assumed that globally shared insubordination is a strong indication of genealogical relatedness.

Reconstructing the pathway of "indirect insubordination" as an inherited mechanism, does not necessarily imply that the insubordination of the suffixes was already completed in ProtoTranseurasian and inherited as finite / nonfinite polysemy in the daughter languages. Rather, the comparative evidence suggests that some of the developments took place on cognate suffixes independently and at different times after separation from Proto-Transeurasian, but nevertheless triggered by the genealogical relationship between these languages. In this way, direct insubordination can be understood as an inherited force, decisive in shaping and reshaping the grammar of the Transeurasian languages.
Abbreviations
a) linguistic terms
ACC accusative
ABL ablative
ADN adnominalizer 

ADV adverbializer
ART article
ASS assertive
COND conditional
CONV converb
DAT dative
DEP dependent
EMPH emphatic
F feminine
FIN finite
FUT future
GEN genitive
INTER interrogative
IPF imperfective
MOD modulator
NOM nominative
NEG negative
NML nominalizer
OBL oblique
PCP participle
PERF perfect
PF perfective
PL plural
POSS possessive
PROC processive
PROX proximal
PRS present
PST past
PT particle
RES resultative
SG singular
VOC vocative

b) languages

$\begin{array}{ll}\text { EMJ } & \text { Early Middle Japanese } \\ \text { Evk. } & \text { Evenki } \\ \text { Ma. } & \text { Manchu } \\ \text { MK } & \text { Middle Korean } \\ \text { MMo. } & \text { Middle Mongolian } \\ \text { Na. } & \text { Nanai } \\ \text { Neg. } & \text { Negidal } \\ \text { OJ } & \text { Old Japanese } \\ \text { OTk. } & \text { Old Turkic } \\ \text { pA } & \text { Proto-Altaic } \\ \text { pJ } & \text { Proto-Japonic } \\ \text { pK } & \text { Proto-Koreanic }\end{array}$




$\begin{array}{ll}\text { pMo } & \text { Proto-Mongolic } \\ \text { pTEA } & \text { Proto-Transeurasian } \\ \text { pTg } & \text { Proto-Tungusic } \\ \text { pTk } & \text { Proto-Turkic } \\ \text { Sd. } & \text { Shodon } \\ \text { Ud. } & \text { Udehe } \\ \text { WMo. } & \text { Written Mongolian } \\ \text { Yo. } & \text { Yonaguni }\end{array}$

c) primary sources

$\begin{array}{ll}\text { K } & \text { 712 Kojiki } \\ \text { KP } & \text { Kalyānamkara ve Papāmkara } \\ \text { Kumkang } & \text { 1464 Kumkang panya phalamil kyeng enhay } \\ \text { MYS } & \text { ca. 759 Man'yōshū } \\ \text { SH } & \text { 1241 Secret History } \\ \text { SK } & \text { Sidi kur } \\ \text { Wel } & \text { 1459 Welin sekpo }\end{array}$

\section{References}

Aikhenvald, Alexandra. 2013. Areal diffusion and parallelism in drift: Shared grammaticalization patterns. In Martine Robbeets \& Hubert Cuyckens (eds.), Shared grammaticalization with special focus on the Transeurasian languages (Studies in Language Companion Series 132), 23-42. Amsterdam: Benjamins.

Anderson, Jeffrey. 2006. Towards a typology of the Siberian linguistic area. In Yaron Matras, April McMahon, and Nigel Vincent (eds.), Linguistic areas. Convergence in historical and typological perspective, 266-300. Basingstoke: Palgrave Macmillan.

Antonov, Anton. 2007. Le rôle des suffixes nominaux en /+rV/ dans l'expression du lieu et de la direction en japonais et l'hypothèse de leur origine “altä̈que”. Paris: Institut National des Langues et Civilisations Orientales Ph.D. dissertation.

Bisang, Walter. 2001. Finite vs. non finite languages. In Martin Haspelmath, Ekkehard König, Wulf Oesterreicher \& Wolfgang Raible (eds.), Language typology and language universals (Handbücher zur Sprach- und Kommunikationswissenschaft), Volume 2, 14001413. Berlin \& New York: Mouton de Gruyter.

Bybee, Joan L. 1985. Morphology: A study of the relation between meaning and form. (Typological studies in language 9.) Amsterdam: Benjamins.

Bybee, Joan, R. Perkins, \& W. Pagliuca.1994. The evolution of grammar: tense, aspect and modality in the languages of the world. Chicago: IL.

Clauson, Gerard. 1972. An etymological dictionary of pre-thirtheenth-century Turkisch. Oxford: Clarendon Press.

Comrie, Bernard. 1976. Aspect: an introduction to the study of verbal aspect and related problems. Cambridge: Cambridge University Press.

DeLancey, Scott. 2011. Finite structures from clausal nominalization in Tibeto-Burman. In Foong Ha Yap, Karen Grunow-Harsta \& Janick Wrona (eds.), Nominalization in Asian languages (Typological Studies in Language 96), 343-359. Amsterdam: John Benjamins. Dressler, Wolfgang U. 1989. Prototypical differences between inflection and derivation. 
Zeitschrift für Phonetik, Sprachwissenschaft und Kommunikationsforschung 42, 3-10.

Dixon, R. M. W. 1972. The Dyirbal language of North Queensland. Cambridge: Cambridge University Press.

Erdal, Marcel 1991. Old Turkic word formation. A functional approach to the lexicon (Turcologica 7). Wiesbaden: Harrassowitz.

Erdal, Marcel 2004. A grammar of Old Turkic. Leiden: Brill.

Evans, Nicholas. 2007. Insubordination and its uses. In Nikolaeva, Irina (ed.), Finiteness. Theoretical and empirical foundations, 366-431. Oxford: Oxford University Press.

Givón, Talmy. 2001. Syntax: An introduction. Vol. 2. Amsterdam: John Benjamins.

Gorelova, Liliya M. 2002. Manchu grammar. Leiden: Brill.

Heath, Jeffrey 1998. Hermit crabs: Formal renewal of morphology by phonologically mediated affix substitution. Language 74. 728-759.

Heine, Bernd \& Mechthild Reh. 1984. Grammaticalization and reanalysis in African languages. Hamburg: Helmut Buske.

Johanson, Lars 1975. Das tschuwaschische Aoristthema. Orientalia Suenica 24, 106-158.

Johanson, Lars 1979. Alttürkisch as 'dissimilierende Sprache'. (Abhandlungen der Akademie der Wissenschaften und der Literatur, Mainz, Geistes-und sozial-wissenschaftliche Klasse 3.) Wiesbaden: Steiner.

Johanson, Lars 2000. Traces of a Turkic copula verb. Turkic Languages 4, 235-238.

Johanson, Lars 2002. Contact-induced change in a code-copying framework. In Mari C. Jones \& Edith Esch (eds.), Language change: The interplay of internal, external and extra-linguistic factors (Contributions to the sociology of language 86), 285-313. Berlin: Mouton de Gruyter.

Johanson, Lars 2012. From the intimate life of Turkic sonorants. Paper presented at the Workshop West Old Turkic: Turkic loanwords in Hungarian, dedicated to Professor András Róna-Tas on the occasion of his 80th birthday. The Szeged Committee of the Hungarian Academy of Sciences, March 11-13, 2012.

Johanson, Lars \& Martine Robbeets. 2010. Introduction. In Lars Johanson \& Martine Robbeets (eds.), Transeurasian verbal morphology in a comparative perspective: genealogy, contact, chance (Turcologica 78), 1-5. Wiesbaden: Harrassowitz.

Joseph, Brian D. 2006. On projecting variation back into a proto-language, with particular attention to Germanic evidence. In Thomas Cravens (ed.), Variation and Reconstruction,103-118. Amsterdam: John Benjamins.

Joseph, Brian D. 2013. Demystifying drift: A variationist account. In Martine Robbeets \& Hubert Cuyckens (eds.), Shared grammaticalization with special focus on the Transeurasian languages (Studies in Language Companion Series 132), 43-65. Amsterdam: John Benjamins.

Kane, Daniel. 2009. The Kitan language and script. Leiden: Brill.

Keller, Rudi. 1994. On Language Change: The invisible hand in language. London: Routledge.

Krüger, John 1961. Chuvash manual. Introduction, grammar, reader and vocabulary. (Uralic and Altaic series 7.) The Hague: Mouton.

Kurylowicz, Jerzy 1965. Zur Vorgeschichte des germanischen Verbalsystems. In: Beiträge zur Sprachwissenschaft, Volkskunde und Literaturforschung: Wolfgang Steinitz zum 60. Geburtstag. Berlin: Akademie-Verlag, 242-247.

LaPolla, Randy J. 1994. Parallel grammaticalizations in Tibeto-Birman languages: Evidence of Sapir's 'drift'. Linguistics of the Tibeto-Burman Area 17(1). 61-80. 
Lee, Ki-Mun \& Ramsey, Robert. 2011. A history of the Korean Language. Cambridge: Cambridge University Press.

Malchukov, Andrej. 2000. Perfect, evidentiality and related categories in Tungusic languages. In Lars Johanson \& Bo Utas (eds.) 2000. Evidentials. Turkic, Iranian and neighbouring languages, 441-469. Berlin: Mouton de Gruyter.

Malchukov, Andrej. 2004. Nominalization / verbalization: constraining a typology of transcategorial operations. München: Lincom.

Malchukov, Andrej 2006. Constraining nominalization: Function/form competition. Linguistics 44.5. 973-1009.

Malchukov, Andrej 2013. Verbalization and insubordination in Siberian languages. In Martine Robbeets \& Hubert Cuyckens (eds.), Shared grammaticalization with special focus on the Transeurasian languages (Studies in Language Companion Series 132), 177208. Amsterdam: John Benjamins.

Malkiel, Yakov. 1981. Drift, slope, and slant: Background of, and variations upon, a Sapirian theme. Language 57(3). 535-557.

Martin, Samuel Elmo. 1970. Shodon: a dialect of the northern Ryukyus. Journal of the American Oriental Society 90(1). 97-139.

Martin, Samuel Elmo. 1987. The Japanese language through time. New Haven: Yale University Press.

Martin, Samuel Elmo. 1992. A reference grammar of Korean. Tokyo: Tuttle.

Martin, Samuel Elmo. 1996. Consonant lenition in Korean and the Macro-Altaic question. Honolulu: University of Hawaii Press.

Martin, Samuel Elmo. 2002. Coming and going: deictic verbs in Korean and Japanese. In Sang-Oak Lee \& Gregory K. Iverson (eds.), Pathways into Korean language and culture : essays in honor of Young-Key Kim-Renaud,373-381. Seoul: Pagijong Press.

Martin, Samuel Elmo. 2006. What do Japanese and Korean have in common?: The history of certain grammaticalizations. Korean linguistics 13. 219-234.

Meillet, Antoine. 1921. Linguistique historique et linguistique générale. Paris: Honoré Champion.

Mithun, Marianne. 2008. The extension of dependency beyond the sentence. Language 84(1).69-119.

Mithun, Marianne. (forthcoming). Shifting finiteness in nominalization: From definitization to refinitization. Finiteness and Nominalization. In Claudine Chamoreau (ed. ). Amsterdam: John Benjamins.

Nedjalkov, Igor 1995. Converbs in Evenki. In Martin Haspelmath \& Ekkehard König (eds.) 1995. Converbs in cross-linguistic perspective. Structure and meaning of adverbial verb forms - adverbial participles, gerunds - (Empirical Approaches to Language Typology 13), 97-136. Berlin: Mouton de Gruyter.

Nedjalkov, Igor V. 1997. Evenki. Descriptive grammar. London: Routledge.

Nikolaeva, Irina 2007. Introduction. In Irina Nikolaeva (ed.) 2007. Finiteness. Theoretical and empirical foundations, 1-19. Oxford: University Press

Orlovskaya, M. N. 1999. Yazyk mongolskikh textov XIII-XIV vv. Moscow: Institut vostokovedeniia RAN.

Plank, Frans. 1998. The covariation of phonology with morphology and syntax: A hopeful history. Linguistic typology 2. 195-230.

Pakendorf, Brigitte. 2009. Intensive contact and the copying of paradigms: an Even dialect in contact with Sakha (Yakut). Journal of language contact 2. 85-110. 
Poppe, Nicholas. 1954. Grammar of Written Mongolian. Wiesbaden: Otto Harrassowitz.

Robbeets, Martine. 2005. Is Japanese related to Korean, Tungusic, Mongolic and Turkic? (Turcologica 64.) Wiesbaden: Harrassowitz.

Robbeets, Martine. 2013a. Genealogically motivated grammaticalization. In: Robbeets, Martine \& Cuyckens, Hubert (eds.), Shared Grammaticalization with special focus on the Transeurasian languages (Studies in Language Companion Series 132), 147-175. Amsterdam: John Benjamins.

Robbeets, Martine. 2013b. A velar fricative in proto-Transeurasian. In: Demir, Nurettin, Karakoç, Birsel \& Menz, Astrid: Turcology and linguistics: Eva Agnes Csato Festschrift. Ankara: Hacettepe Üniversitesi Yayınları, 375-400.

Robbeets, Martine. (forthcoming). Japanese and the Transeurasian verb system (Typological Studies in Language). Berlin: Mouton-De Gruyter.

Robbeets, Martine. 2015 (submitted). The development of finiteness in the Transeurasian languages. In Björn Wiemer and Alexander Letuchiy (eds.) Clausal complements in Eurasian Languages (Linguistics special issue).

Sárközi, Alice. 2004. Classical Mongolian. München: LINCOM.

Sapir, Edward. 1921. Language. New York: Harcourt, Brace \& World.

Street, John. 1957. The language of the Secret History of the Mongols. New Haven: American Oriental Society.

Trask, Robert Lawrence. 1993. A dictionary of grammatical terms in linguistics. London: Routledge.

Vovin, Alexander. 2009. A descriptive and comparative grammar of Western Old Japanese. Part 2: adjectives, verbs, adverbs, conjunctions, particles, postpositions. (Languages of Asia 8.) Folkestone: Global Oriental.

Weiers, Michael. 1966. Untersuchungen zu einer historischen Grammatik des präklassischen Schriftmongolisch. Bonn: Rheinischen Friedrich-Wilhelms-Universität Ph.D dissertation.

Werner, Heinrich. 1997. Die ketische Sprache. Wiesbaden: Harrassowitz.

Wrona, Janick. 2008. The nominal and adnominal forms in Old Japanese: Consequences for a reconstruction of pre-Old Japanese syntax. In Bjarke Frellesvig \& John Whitman (eds.) 2008. Proto-Japanese. Issues and prospects. (Current Issues in Linguistic Theory 294), 193-215. Amsterdam: John Benjamins.

The research leading to these results has received funding from the European Research Council under the Horizon 2020 Program/ ERC Grant Agreement n. 646612 granted to Martine Robbeets. 